http://jmscr.igmpublication.org/home/ ISSN (e)-2347-176x ISSN (p) 2455-0450 crossref DOI: https://dx.doi.org/10.18535/jmscr/v8i3.87

\title{
Bacteriological profile of multidrug resistant Gram negative bacilli causing urinary tract infection in paediatric age group in a tertiary care centre
}

\author{
Authors \\ Lijitha S.G ${ }^{1}$, Resmi Rajan ${ }^{* *}$, Karthika $S^{3}$, Sabu Thomas ${ }^{4}$ \\ ${ }^{1}$ Junior Resident, Dept of Microbiology, Government Medical College, Trivandrum-695011, Kerala \\ ${ }^{2}$ Professor, Dept of Microbiology, Government Medical College, Calicut- 673008, Kerala \\ ${ }^{3}$ Research Scholar, Cholera and biofilm research laboratory, Rajiv Gandhi centre for biotechnology, \\ Trivandrum-695014, Kerala \\ ${ }^{4}$ Scientist, Cholera and biofilm research laboratory, Rajiv Gandhi centre for biotechnology, \\ Trivandrum-695014, Kerala \\ *Corresponding Author \\ Resmi Rajan
}

\begin{abstract}
Introduction: Urinary tract infection is among the most common causes of febrile illness in children. It can lead to complications including septicaemia, if appropriate therapy is not given. Drug resistance has emerged as a significant problem in treating UTI. Knowing the pattern of antimicrobial resistance will help the clinicians in prescribing antibiotics.
\end{abstract}

Aims and Objectives: To determine the proportion of multidrug resistant Gram negative bacilli causing urinary tract infection in paediatric age group, antibiotic susceptibility pattern and detection of genes conferring resistance.

Materials and Methods: This is a descriptive study in which a total of 480 Gram negative urinary isolates from children less than 12 years over a period of 1 year were included. Multidrug resistant isolates were subjected to phenotypic confirmatory tests for ESBL, MBL, AmpC. 104 randomly selected isolates were subjected to PCR for CTX, TEM, SHV and VIM genes.

Results: Majority of isolates were from males.72.9\% of isolates were multidrug resistant. Majority of the isolates were E coli followed by Klebsiella pneumoniae, Pseudomonas aeruginosa, Acinetobacter baumannii, Proteus mirabilis, Klebsiella oxytoca, Proteus vulgaris and Citrobacter freundii. Acinetobacter baumannii had the largest number (76.9\%) of multidrug resistant isolates. $47.2 \%$ of the MDR isolates were ESBL producers, $11.6 \%$ were AmpC producers and $11.2 \%$ were MBL producers. $85 \%$ of the ESBL producing isolates tested had CTX M gene and $22 \%$ had TEM gene. 1 out of the 4 MBL producing Pseudomonas aeruginosa isolates tested had VIM gene.

Conclusion: The study emphasize the need for surveillance and development of local and paediatric specific antibiograms to reduce the growing resistance rates.

Keywords: $E S B L, M B L$, paediatric UTI, TEM, CTX-M.

\section{Introduction}

Urinary tract infection (UTI) is among the most common causes of febrile illness in children and is an important cause of mortality in developing countries. The prevalence of UTI varies with age. The male:female ratio is $2.8-5.5: 1$ in the first year 
of age. There is a female preponderance beyond 1-2 years. Factors that influence the development of UTI include female gender, anatomical and physiological abnormalities of urogenital tract, iatrogenic factors such as catheter related infection, low immune status etc.

Most UTIs are caused by Gram negative bacteria, of which Escherichia coli is the most common (> $75 \%$ ) as in adult UTIs. Other organisms include Klebsiella spp, Proteus spp, Enterobacter spp, Citrobacter spp, Pseudomonas aeruginosa, Serratia spp, Enterococcus spp. The main consequences of inappropriately treated UTI in children include chronic renal damage, end stage renal insufficiency and arterial hypertension.

Multidrug resistance (MDR) is defined as acquired non susceptibility to at least one agent in three or more antimicrobial classes. Recently, studies on paediatric UTI are showing an increase in drug resistance among uropathogens, with $23.3 \%$ of E.coli, $23.5 \%$ of Klebsiella spp, $25 \%$ of Proteus spp being multidrug resistant ${ }^{1}$. This has occurred probably due to empirical therapy and misuse of antibiotics. The commonest mechanism of acquired drug resistance in most Enterobacteriaceae is the production of betalactamases. This study was conducted to determine the proportion of MDR Gram negative bacilli causing paediatric UTI. their antibiotic susceptibility pattern and to detect the extended spectrum betalactamase (ESBL) and metallobetalactamase (MBL) genes in these organisms.

\section{Materials and Methods}

This was a hospital based descriptive study conducted at the Department of Microbiology, SAT hospital, a 1000-bedded tertiary health-care centre, Trivandrum, Kerala, for a period of 1 year from $1^{\text {st }}$ July $2016-30^{\text {th }}$ June 2017 . A total of 480 Gram negative isolates from urine specimens of children less than 12 years recieved in SAT microbiology laboratory were included. Midstream urine, suprapubic aspirates and catheter specimens were included. Study was started after obtaining clearance from institutional ethics committee (IEC.No.06/12/2015/MCT). All samples were processed as per standard protocol ${ }^{2}$ and isolates were identified using standard biochemical reactions. Antibiotic susceptibility testing was done according to CLSI recommended Kirby Bauer disc diffusion testing method for Ampicillin $(25 \mu \mathrm{g})$, Gentamicin $(10 \mu \mathrm{g}), \quad 1 \mathrm{st}$ generation Cephalosporin $(30 \mu \mathrm{g})$, Ciprofloxacin $(5 \mu \mathrm{g})$, Amikacin $(10 \mu \mathrm{g})$, Ceftriaxone $(30 \mu \mathrm{g})$, Ceftazidime $\quad(30 \mu \mathrm{g}), \quad$ Piperacillin-tazobactam $(100 / 10 \mu \mathrm{g})$, Nalidixic acid $(30 \mu \mathrm{g})$, Norfloxacin $(10 \mu \mathrm{g})$ Cotrimoxazole $(1.25 / 23.75 \mu \mathrm{g})$, Nitrofurantoin $(300 \mu \mathrm{g})$, Meropenem $(10 \mu \mathrm{g})$, Imipenem $(10 \mu \mathrm{g})$, Cefepime $(30 \mu \mathrm{g})$ discs.

Phenotypic tests for ESBL, Amp C beta lactamases, MBL were done on multidrug resistant isolates ${ }^{3,4}$.

\section{For detecting ESBL producers}

1) Screening test done was CLSI recommended disc diffusion test using Ceftazidime $(30 \mu \mathrm{g})$ and Cefotaxime $(30 \mu \mathrm{g})$. Isolates with a zone size $\leq$ $22 \mathrm{~mm}$ for Ceftazidime and/ or $\leq 27 \mathrm{~mm}$ for Cefotaxime were subjected to confirmatory testing.

2) Confirmatory test done was CLSI recommended Cephalosporin/ clavulanate combination disc test in which antibiotic discs of Ceftazidime $(30 \mu \mathrm{g})$ and Ceftazidime-clavulanic acid $(30 / 10 \mu \mathrm{g}), \quad$ Cefotaxime $(30 \mu \mathrm{g})$ and Cefotaxime-clavulanic acid $(30 / 10 \mu \mathrm{g})$ were used.The organism is considered an ESBL producer if Cephalosporin/clavulanate combination disc showed a zone diameter $\geq 5 \mathrm{~mm}$ than Cephalosporin disc alone.

\section{For detecting AmpC producers,}

1) Screening test done was CLSI recommended disc diffusion test using Cefoxitin $(30 \mu \mathrm{g})$. Isolates with a zone size $\leq 14 \mathrm{~mm}$ are subjected to confirmatory testing.

2) Confirmatory test done was combined disc diffusion test using phenyl boronic acid in which antibiotic discs of Cefoxitin $(30 \mu \mathrm{g})$ alone and Cefoxitin(30 $\mu \mathrm{g})$ in combination with $400 \mu \mathrm{g}$ phenyl boronic acid were used. The organism is 
considered an Amp C producer if Cefoxitin phenyl boronic acid combination disc showed a zone diameter $\geq 5 \mathrm{~mm}$ than Cefoxitin disc alone.

\section{For detecting MBL producers}

1) Screening test done was CLSI recommended disc diffusion test using Ertapenem $(10 \mu \mathrm{g})$ and Meropenem $(10 \mu \mathrm{g})$. Isolates with a zone size $\leq$ $18 \mathrm{~mm}$ for Ertapenem and/ or $\leq 19 \mathrm{~mm}$ for Meropenem are subjected to confirmatory testing.

2) Confirmatory test done was CLSI recommended combined Imipenem EDTA disc test in which antibiotic discs of Imipenem $(10 \mu \mathrm{g})$ and Imipenem EDTA $(10 / 750 \mu \mathrm{g})$ were used. The organism is considered an MBL producer if Imipenem EDTA combination disc showed a zone diameter $\geq 7 \mathrm{~mm}$ than Imipenem disc alone

\section{Molecular characterisation of ESBL and MBL}

Molecular characterisation was done only on $30 \%$ of MDR isolates. Uniplex polymerase chain reaction (PCR) was done for the detection of TEM and CTX $M$ genes in 100 randomly selected ESBL producers and for SHV genes in 5 randomly selected ESBL producers. PCR for detecting VIM gene was done only in $4 \mathrm{MBL}$ producing Pseudomonas aeruginosa isolates.

\section{Preparation of DNA template}

DNA template was prepared by growing fresh culture of the test organism and control strains overnight in a shaking incubator in Mueller Hinton broth followed by centrifugation. The pellet is resuspended in sterile milli-Q (double distilled water), heated at $80^{\circ} \mathrm{C}$ in a water bath for 20 minutes, chilled immediately and stored at $20^{\circ} \mathrm{C}$.

PCR amplification of the target DNA was carried out in a thermal cycler (Master cycler Eppendorf) in $0.2 \mathrm{ml} \mathrm{PCR}$ tubes with a reaction mixture volume of $20 \mu \mathrm{l}$ containing 20 Pico moles of forward and reverse primers each (Table 1), $1.5 \mathrm{mM} \mathrm{MgCl} 2(2 \mu \mathrm{l}), 200 \mu \mathrm{M}$ dNTPs $(1.5 \mu \mathrm{l}), 1 \mathrm{X}$ PCR buffer $(2 \mu \mathrm{l})$ (Sigma), and 1.5U of Taq DNA polymerase $(0.3 \mu 1)$ (Sigma), $1 \mu 1$ of DNA template and sterile water to a final volume of $20 \mu 1$.

Thermal cycling conditions for CTX -M,TEM and VIM includes initial denaturation at $94^{\circ} \mathrm{C}$ for 5 minutes followed by 30 cycles of denaturation at $94^{\circ} \mathrm{C}$ for 1 minute, annealing at $54^{\circ} \mathrm{C}$ for 1 minute, extension at $72^{\circ} \mathrm{C}$ for 1 minute, followed by final extension at $72^{\circ} \mathrm{C}$ for 10 minute and hold at $4^{\circ} \mathrm{C}$. Thermal cycling conditions for SHV includes initial denaturation at $94^{\circ} \mathrm{C}$ for 4 minutes followed by 30 cycles of denaturation at $94^{\circ} \mathrm{C}$ for 45 seconds, annealing at $52^{\circ} \mathrm{C}$ for 45 seconds, extension at $72^{\circ} \mathrm{C}$ for 1 minute 50 seconds, followed by final extension at $72^{\circ} \mathrm{C}$ for 10 minute and hold at $4^{\circ} \mathrm{C}$.

Amplified products were separated by gel electrophoresis on $1 \%$ agarose gel, stained with ethidium bromide and visualized by using gel documentation system, Fluro S multi imager (Bio rad, USA).(Figure 1, 2,3,4)

Table 1: Primer sequences used in the study $y^{5,6,7}$

\begin{tabular}{|l|l|c|}
\hline Primer & Sequence 5'........ & Amplicon size \\
\hline TEM & $\begin{array}{l}\text { ATA AAA TTC TTG AAG ACG AAA } \\
\text { GAC AGT TAC CAA TGC TTA ATC }\end{array}$ & $1080 \mathrm{bp}$ \\
\hline CTX-M & $\begin{array}{l}\text { SCS ATG TGC AGY ACC AGT AA } \\
\text { CCG CRA TAT GRT TGG TGG TG } \\
\text { S= G or C, R = A or T }\end{array}$ & $544 \mathrm{bp}$ \\
\hline VIM & $\begin{array}{l}\text { GTT TGG TCG CAT ATC GCA AC } \\
\text { AAT GCG CAG CAC CAG GAT AG }\end{array}$ & $382 \mathrm{bp}$ \\
\hline SHV & $\begin{array}{l}\text { ATT TGT CGC TTC TTT ACT CGC } \\
\text { TTT ATG GCG TTA CCT TTG ACC }\end{array}$ & $1018 \mathrm{bp}$ \\
\hline
\end{tabular}

\section{Results}

In the study population, $58 \%$ were males and $42 \%$ were females. Maximum number of isolates were from the age group of 28 days to 1 year, (42\%), followed by 1 - 3 year age group (22.5\%) and 5-12 year age group (19\%). Remaining $16.5 \%$ of isolates were from the age group of 3-5 years and $<28$ days, of which least number were from $<28$ 
days age group. Majority of the isolates were $E$ coli $(66 \%)$, followed by Klebsiella pneumoniae (23\%), Pseudomonas aeruginosa (3.8\%), Acinetobacter baumannii (2.8\%). The remaining $4.6 \%$ were constituted by Proteus mirabilis, Klebsiella oxytoca, Proteus vulgaris and Citrobacter freundii.
Susceptibility pattern of $E$ coli ( largest number of isolates) shows a higher rate of susceptibility to Nitrofurantoin $(87.7 \%)$, Piperacillin- tazobactam (78.3 \%), Meropenem (76.1\%) and Amikacin $(58 \%)$ compared to other antibiotics. (Chart 1)

Chart 1: Antibiotic susceptibility pattern of isolates (percentage of sensitivity)

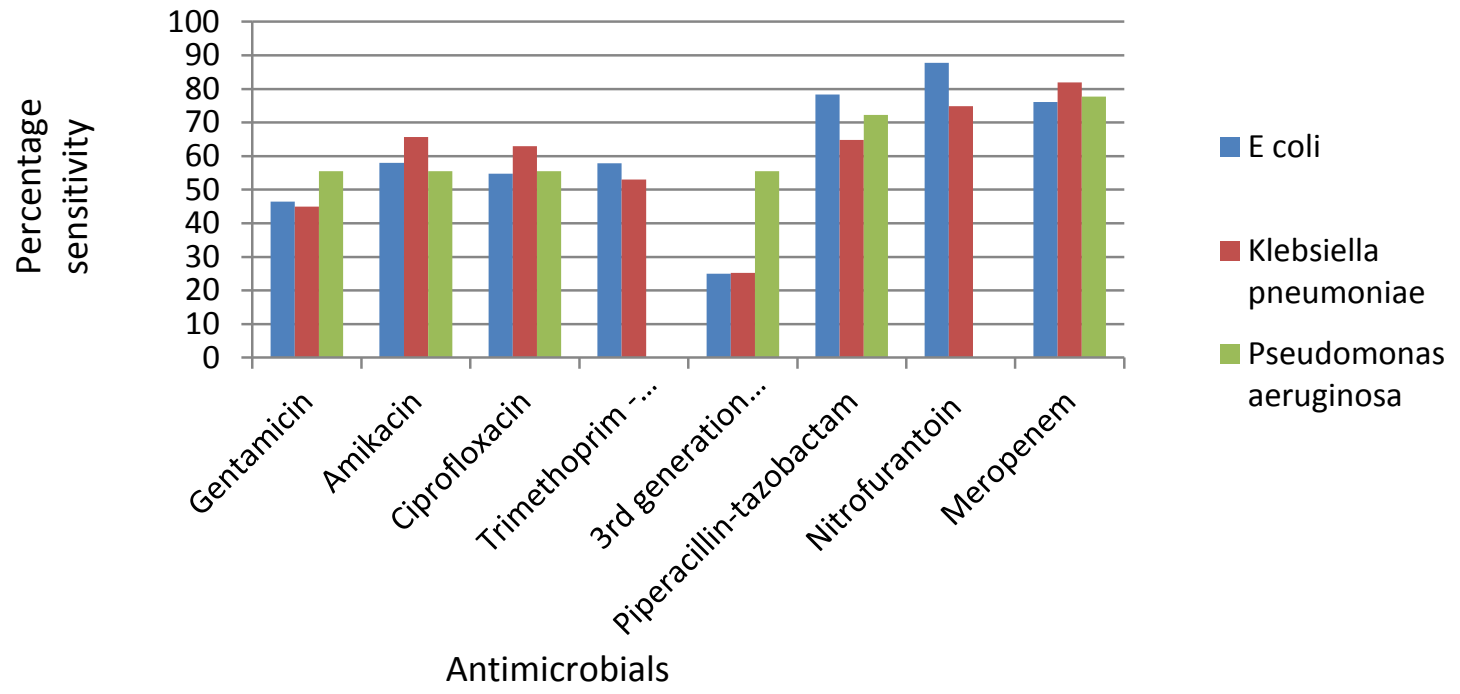

$72.9 \%$ of total isolates were resistant to 3 or more classes of antibiotics (MDR). Considering the number of MDR isolates among the individual organisms, Acinetobacter baumannii had the largest number $(76.9 \%)$ (Table 2).

Out of the total 480 isolates, $47.2 \%$ were ESBL producers. $11.6 \%$ were AmpC producers and 11.2 $\%$ were MBL producers. In all organisms except Pseudomonas aeruginosa and Acinetobacter baumannii, among the total isolates ESBL producers were found to be more, followed by AmpC and MBL producers. In Pseudomonas aeruginosa isolates, MBL production was high (22.2\%) as compared to ESBL (16.7\%) and AmpC (5.5\%) production. Among Acinetobacter isolates, ESBL production was high (38.4\%) followed by MBL (30.7\%) and AmpC (7.6\%) production.

Table 2: Distribution of MDR organisms among the isolates

\begin{tabular}{|l|c|c|c|}
\hline Organism & $\begin{array}{c}\text { Total number of } \\
\text { isolates }\end{array}$ & $\begin{array}{c}\text { Number of MDR } \\
\text { organisms }\end{array}$ & Percentage \\
\hline E coli & 318 & 238 & $74.8 \%$ \\
\hline Klebsiella pneumoniae & 111 & 83 & $74.7 \%$ \\
\hline Klebsiella oxytoca & 7 & 5 & $71.4 \%$ \\
\hline Proteus vulgaris & 3 & 2 & $66.6 \%$ \\
\hline Proteus mirabilis & 8 & 3 & $37.5 \%$ \\
\hline $\begin{array}{l}\text { Pseudomonas } \\
\text { aeruginosa }\end{array}$ & 18 & 10 & $44.4 \%$ \\
\hline $\begin{array}{l}\text { Acinetobacter } \\
\text { baumannii }\end{array}$ & 13 & 1 & $76.9 \%$ \\
\hline Citrobacter freundii & 2 & 350 & $50 \%$ \\
\hline Total & 480 & & $72.9 \%$ \\
\hline
\end{tabular}


Table 3: Distribution of ESBL genes among the MDR isolates tested

\begin{tabular}{|l|c|c|c|c|c|}
\hline Organism & $\begin{array}{c}\text { Isolates tested } \\
\text { for CTX M } \\
\text { \&TEM }\end{array}$ & $\begin{array}{c}\text { Isolates } \\
\text { tested for } \\
\text { SHV }\end{array}$ & $\begin{array}{c}\text { CTX M } \\
\text { present }\end{array}$ & $\begin{array}{c}\text { TEM } \\
\text { present }\end{array}$ & $\begin{array}{c}\text { SHV } \\
\text { present }\end{array}$ \\
\hline Ecoli & 73 & 3 & $63(86.3 \%)$ & $10(13.6 \%)$ & $3(100 \%)$ \\
\hline $\begin{array}{l}\text { Klebsiella } \\
\text { pneumoniae }\end{array}$ & 25 & 1 & $22(88 \%)$ & $11(44 \%)$ & 0 \\
\hline $\begin{array}{l}\text { Klebsiella } \\
\text { oxytoca }\end{array}$ & 1 & 1 & 0 & 0 & 0 \\
\hline $\begin{array}{l}\text { Proteus } \\
\text { mirabilis }\end{array}$ & 1 & 0 & 0 & $1(100 \%)$ & 0 \\
\hline Total & 100 & 5 & $85(85 \%)$ & $22(22 \%)$ & $3(60 \%)$ \\
\hline
\end{tabular}

CTX M gene was detected in $85 \%$ of the isolates tested, TEM gene in $22 \%$, SHV gene in $60 \%$ (Table 3).CTX M + TEM genes were detected in $17 \%$ of isolates tested. CTX M + SHV genes were detected in $40 \%$ of isolates tested (Table 3 ).
Among the total $54 \mathrm{MBL}$ producing organisms, there were 4 Pseudomonas aeruginosa isolates. All the 4 isolates were subjected to PCR for detection of VIM gene. Only 1(25\%) isolate showed presence of VIM gene.

Figure 1,2,3,4: PCR assay for CTX M, TEM, SHV and VIM genes

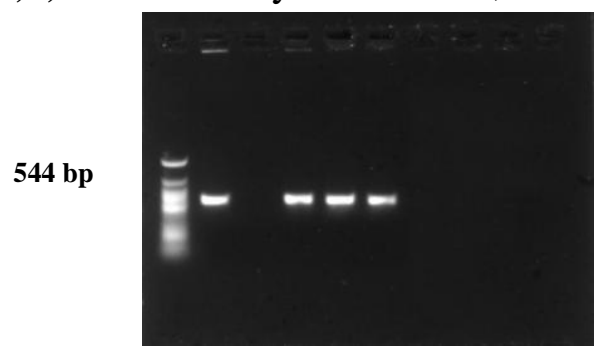

Lane $1 \quad 2 \quad 3 \quad 4 \quad 5 \quad 6$

PCR assay for CTX M gene showing : -

Lane 1 - 100 b p ladder (NEB), Lane 3 - negative control,

Lane 2 - positive control ,Lane 4,5,6-CTX M positive isolates.

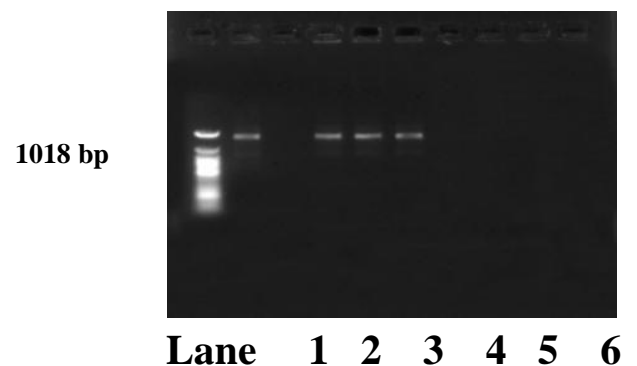

PCR assay for SHV gene showing:-

Lane 1- 100 bp ladder (NEB), Lane 3 - negative control,

Lane 2 - positive control, Lane 4, 5, 6-SHV positive isolates

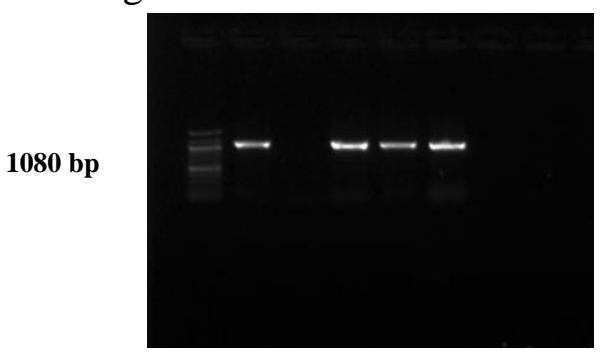

Lane $1 \quad 2 \quad 3 \quad 4 \quad 56$

PCR assay for TEM gene showing :-

Lane $1-100 \mathrm{~b}$ p ladder (NEB), Lane 3 - negative control

Lane 2 - positive control, Lane 4, 5,6 - TEM positive isolates

382 bp

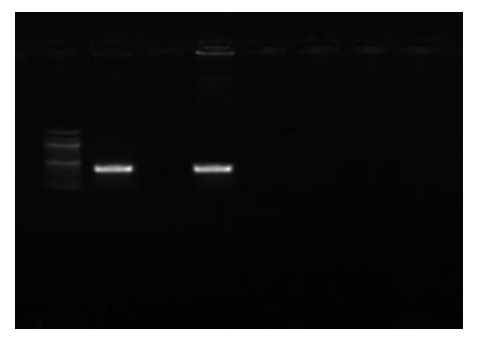

Lane $\begin{array}{llll}1 & 2 & 3 & 4\end{array}$

PCR assay for VIM gene showing:-

Lane 1 - 100 bp ladder (NEB), Lane 3 - negative control

Lane 2 - positive control, Lane 4 - VIM positive isolate

\section{Discussion}

The study shows a male predominance which correlates well with another study conducted in children upto 12 years of age by Krishnan et al in a tertiary care centre in Kerala ${ }^{10}$. Majority of the isolates were from the age group of 28 days to 1 year ; but a similar study from northern Kerala shows increased prevalence of UTI in 1-5 year age group $^{8}$. Considering the etiological agents, similar findings as that of the present study were observed in other studies conducted by Taneja et al and Krishnan et al from different geographical area ${ }^{8,9}$. A higher percentage of susceptibility of $E$ coli to Nitrofurantoin, Meropenem, Piperacillintazobactam was seen in the present study. Studies conducted by Nagaraj et al and Nisha K.V et al on 
paediatric UTI also show similar antimicrobial susceptibility pattern ${ }^{10,11}$.

The percentage of multidrug resistant isolates identified in this study is much higher than that found in other studies ${ }^{12}$. ESBL producers were found to outnumber AmpC and MBL producers in all isolates except Pseudomonas aeruginosa and Acinetobacter baumannii in this study; whereas varying results were obtained in other studies. In a study conducted in South Kerala by Anitha Madhavan et al, AmpC producers were more than ESBL and MBL producers ${ }^{13}$. But the present study shows a reduced prevalence of MBLs among Enterobacteriaceae compared to other studies ${ }^{14}$ probably because of the judicious use of carbapenems. However, among Pseudomonas aeruginosa isolates, MBL producers were seen more than ESBL and AmpC producers in this study, which is in parallel with the findings of a similar study conducted by Umadevi et al ${ }^{15}$.

In the study CTX M gene was the most common ESBL gene detected, followed by SHV and TEM gene. In other studies also CTX gene was the most prevalent gene. However TEM gene followed next and SHV gene came only as the third prevalent gene $^{11}$. CTX $M+$ TEM genes were detected in $17 \%$ of isolates tested and CTX M + SHV in $40 \%$ .A study on ESBL producing Enterobacteriaceae by Kaur $\mathrm{M}$ et al also had similar results ${ }^{16}$. $25 \%$ of Pseudomonas aeruginosa isolates tested had VIM gene. A study conducted in Kerala on carbapenem resistant isolates by Anjali Swaminathan et al in 2016 showed that $50 \%$ of MBL producing Pseudomonas aeruginosa isolates had VIM gene ${ }^{17}$.

Tests to detect inducible AmpC producers, ESBL and AmpC co-producers were not done .

\section{Conclusion}

Majority of the isolates were from males. Maximum number of isolates were from age group of 28 days to 1 year .Largest number of isolates were E coli.72.9\% of the total isolates showed multidrug resistance .Acinetobacter baumannii had the largest number of multidrug resistant isolates. Largest number of isolates were ESBL producers followed by AmpC producers and MBL producers. CTX $\mathrm{M}$ was the most prevalent ESBL coding gene detected followed by SHV and TEM. Among the multiple gene combinations present in ESBL producers, CTX M $+\mathrm{SHV}$ was found to be more compared to CTX M + TEM. The study emphasises the need for periodic surveillance to identify the antibiotic resistance and formulation of local antibiograms especially paediatric specific antibiograms to guide clinicians in treating paediatric UTI, so that the emergence of MDR organisms can be effectively controlled.

\section{Acknowledgement}

Our acknowledgement to Prof. M. Radhakrishna Pillai, Director, Rajiv Gandhi Centre for Biotechnology, Trivandrum, Kerala, India for permitting to conduct molecular work in the institution

Financial support and sponsorship: Financial support was provided by SBMR

Conflicts of interest: There are no conflicts of interest

\section{References}

1. Goel S, Mukherjee SB. Urinary Tract Infection - A Tale of 50 Years. Indian Pediatr 2016. 2016;(53):57-8.

2. Collee G, Duguid P, Fraser G, Marmian P. Mackey and MacCartney's Practical Medical Microbiology. 14th ed. Vol. 2. Churchill Livingstone Publishers. Longman Singapore. 2003.

3. CLSI Performance standards for Antimicrobial Susceptibility testing, $27^{\text {th }}$ Informational supplement,CLSI document M100 S-27,Vol 36.Wayne, P A : Clinical and Laboratory Standards Institute , 2016

4. Coudron PE. Inhibitor-Based Methods for Detection of Plasmid-Mediated AmpC $\beta$ Lactamases in Klebsiella spp., Escherichia coli, and Proteus mirabilis. J Clin Microbiol. 2005 Aug;43(8):4163-7. 
5. Conceição T, Brízio A, Duarte A, Lito LM, Cristino JM, Salgado MJ. First Description of CTX-M-15-Producing Klebsiella pneumoniae in Portugal. Antimicrob Agents Chemother. 2005 Jan;49(1):477-8.

6. Vacheva-Dobrevsky R, Jacoby GA. Epidemiology of Extended-Spectrum $\beta$ Lactamases in Sofia, Bulgaria. Eur J Clin Microbiol Infect Dis. 2003 Jun;22(6):385-8.

7. Fallah F, Borhan RS, Hashemi A. Detection of bla(IMP) and bla(VIM) metallo- $\beta$-lactamases genes among Pseudomonas aeruginosa strains. Int J Burns Trauma. 2013 Apr 18;3(2):122-4.

8. Krishnan C, Gireeshan VK, Nimmi JE, Sabitha S, Vimalraj NA, Biju G. Clinicobacteriological profile of urinary tract infections in children and resistance pattern of uropathogens- a study from south india. J Evid Based Med Healthc. 2017 Feb 1;4(15):85963.

9. Taneja, N. Chatterjee, SS. Singh, M. Singh, S. and Sharma, M. 2010. Pediatric urinary tract infections in a tertiary care center from northern India. Ind. J. Med. Res. 131: 101-105.

10. Nagaraj S, Kalal B, Kamath N, Muralidharan S. Microbiological And Antimicrobial Profile Of Pathogens Associated With Pediatric Urinary Tract Infection: A One Year Retrospective Study From A Tertiary Care Teaching Hospital. National Journal of Laboratory Medicine. 2014 Mar, Vol 3(1): 4-7

11. Nisha KV, Shenoy RD, Shetty AV, Shenoy VM and Shetty AK. Trends in antimicrobial resistance among uropathogens with special reference to $E$. coli in community acquired pediatric urinary tract infections from Kerala. J Evol Medical and Dental Sci. 2015;4(54):9313-20

12. Jitendranath A, Radhika R, Bhargavi L, Bhai G, Beevi R. Microbiological Profile of Urinary Tract Infection in Pediatric Population from a Tertiary Care Hospital in South Kerala. Journal of Bacteriology \& Mycology: Open Access. 2015; 1(1):1-5.. 2013
13. Madhavan A, Jayalakshmi V. Occurrence of extended-spectrum beta-lactamase, AmpC and MBLase producers among multidrug-resistant Enterobacteriaceae causing urinary tract infection in a tertiary health-care teaching hospital. $J$ Acad Clin Microbiol. 2016;18(2):80-5.

14. Sharma M, Yadav S, Chaudhary U. Metallobeta-lactamase Producing Pseudomonas aeruginosa in Neonatal Septicemia. J Lab Physicians. 2010;2(1):14-6.

15. Umadevi S, Joseph NM, Kumari K, Easow JM, Kumar S, Stephen S, et al. Detection of extended spectrum beta lactamases, ampc beta lactamases and metallobetalactamases in clinical isolates of ceftazidime resistant Pseudomonas aeruginosa. Braz J Microbiol. 2011;42(4):1284-8.

16. Kaur M, Aggarwal A. Occurrence of the CTXM, SHV and the TEM Genes Among the Extended Spectrum $\beta$-Lactamase Producing Isolates of Enterobacteriaceae in a Tertiary Care Hospital of North India. J Clin Diagn Res JCDR. 2013 Apr;7(4):642-5.

17. Swaminathan A, Ardra M, Manoharan A, Nair K, Girija K. Characterisation of carbapenemase-producing Gram-negative bacilli among clinical isolates in a tertiary care centre in Kerala, South India. J Acad Clin Microbiol. 2016;18(2):100-4. 